\title{
Persepsi Mahasiswa Terhadap Kegiatan Kaiwakai Tahun 2016-2017 di Program Studi Diploma III Bahasa Jepang Sekolah Vokasi UGM
}

\author{
Mery Kharismawati \\ Sekolah Vokasi, Universitas Gadjah Mada \\ Mery.kharismawati@ugm.ac.id
}

\begin{abstract}
Abstrak
Untuk menunjang keterampilan berbicara dalam berbahasa Jepang, Program D-III Bahasa Jepang Sekolah Vokasi UGM menyelenggarakan kegiatan Kaiwakai. Pada kegiatan ini mahasiswa berkesempatan untuk berinteraksi dengan penutur asli secara bebas dan santai di luar jadwal perkuliahan. Penelitian ini bertujuan mengetahui persepsi mahasiswa terhadap kegiatan Kaiwakai tahun 2016-2017 di program studi D-III Bahasa Jepang Sekolah Vokasi UGM. Metode pengumpulan data dilakukan dengan cara observasi langsung dan wawancara semiterstruktur pada 6 peserta kegiatan Kaiwakai tahun 2016-2017. Hasil penelitian menunjukkan bahwa kegiatan Kaiwakai perlu untuk digiatkan di kalangan mahasiswa karena memiliki pengaruh positif bagi seorang pembelajar Bahasa Jepang, yaitu karena dapat meningkatkan kemampuan bahasa Jepang. Manfaat kegiatan Kaiwakai diperoleh setelah beradaptasi dengan kendala, berupa rasa tidak percaya diri pada kemampuan bahasa Jepang yang muncul selama mengikuti Kaiwakai.
\end{abstract}

Kata kunci: Kaiwakai, Bahasa Jepang, Persepsi.

\section{Pendahuluan}

Bahasa Jepang (BJ) merupakan salah satu bahasa asing yang menjadi favorit bagi pembelajar bahasa asing di Indonesia. Berdasarkan sejarahnya, penyelenggaraan Pendidikan BJ pada lembaga pendidikan formal di Indonesia sudah berjalan cukup lama. Hal ini diawali dengan penempatan pelajaran BJ sebagai pelajaran minor pada beberapa SMA di Jawa Barat di tahun1960-an. Kemudian berdirilah Jurusan Sastra Jepang Universitas Padjajaran, disusul IKIP Bandung. Lulusan kedua institusi ini kemudian menjadi pengajar BJ di Jawa Barat, dan meluas hingga ke berbagai Perguruan Tinggi di Indonesia (Momose (1998), Furukawa (2015) dalam Sutedi, 2017). Pada perkembangannya, sekarang ini di Indonesia terdapat 2.496 institusi yang menawarkan BJ, dan di antaranya adalah Sekolah Vokasi UGM yang menawarkan jurusan BJ untuk jenjang Diploma III (D-III) (The Japan Foundation, 2017).

Pendidikan D-III di UGM mengusung pendidikan vokasional yang mengutamakan praktik daripada teori. Dengan perbandingan prosentase sekitar $70 \%$ praktik dan $30 \%$ teori, Program Studi D-III Bahasa Jepang dituntut untuk menyelenggarakan pembelajaran yang berorientasi pada praktik yang diharapkan dapat menghasilkan lulusan yang terampil berbahasa Jepang baik lisan maupun tulis.

Untuk dapat terampil berbahasa Jepang, terdapat empat aspek yang harus dikuasai oleh seorang pembelajar bahasa. Empat aspek ini mencakup keterampilan berbicara, membaca, mendengarkan/menyimak, dan menulis. Dewasa ini keterampilan berbicara BJ memiliki daya saing yang tinggi di bursa lowongan kerja. Rata-rata perusahaan Jepang di Indonesia mensyaratkan kemampuan berbahasa Jepang minimal setara JLPT Level N3. 
Di level ini lulusan Program Studi BJ diharapkan dapat memahami bacaan sederhana, memahami percakapan sederhana dengan kecepatan bicara normal, menguasai 650 kanji, dan mengenal 3.750 kata dalam BJ. Selain itu, seringkali ada lowongan yang mengharuskan pembelajar BJ berinteraksi dengan orang Jepang secara langsung.

Sehubungan dengan kebutuhan pasar akan penutur BJ di atas, dalam pembelajaran BJ, pengajar di Program Studi D-III Bahasa Jepang SV UGM bercita-cita menghasilkan lulusan yang fasih berbahasa Jepang. Hal ini sesuai dengan pendapat Piller (2002) yang mengasumsikan bahwa di bidang pemerolehan bahasa ke dua, merupakan hal yang umum jika kemampuan pembelajar akan dibandingkan dengan penutur bahasa asli dari bahasa yang dipelajari tersebut. Dengan kata lain, dalam konteks pendidikan, pengajar akan berusaha mengubah anak didiknya menjadi penutur asli, atau membuat mereka mencapai tingkat mendekati keaslian (Piller dalam Andreou \& Galantomos, 2009).

Salah satu cara mencapai cita-cita ini, Program Studi D-III Bahasa Jepang SV UGM membuat sebuah kegiatan bernama Kaiwakai. Dalam kegiatan ini, mahasiswa diharapkan dapat lebih memahami karakteristik orang Jepang, di samping membiasakan diri berinteraksi dengan orang Jepang dan mempraktekkan apa yang telah dipelajari di kelas. Hasil observasi yang dilakukan oleh penulis yang menjadi dosen di UGM di tahun 2015 dan menjadi penanggung jawab kegiatan Kaiwakai di tahun 2016-2017 menunjukkan bahwa kegiatan ini mengalami animo yang naik turun. Dengan latar belakang tersebut, penelitian kali ini memfokuskan pada persepsi mahasiswa terhadap kegiatan Kaiwakai.

Pengumpulan data yang digunakan dalam penelititian ini adalah dengan metode wawancara semiterstruktur terhadap 6 peserta Kaiwakai yang merupakan mahasiswa angkatan 2015 (3 orang) dan 2017 (3 orang). Setelah data wawancara yang berbentuk audio terkumpul, data tersebut diketik dalam bentuk teks untuk dapat menyaring persepsi responden terhadap kegiatan Kaiwakai. Data kemudian disarikan menggunakan metode triangulasi, yaitu pengecekan keabsahan data dengan menggunakan sumber data yang lain, yaitu dokumentasi dan hasil observasi pada beberapa pelaksanaan kegiatan Kaiwakai 2016-2017.

\section{Pembahasan}

\section{a. Kegiatan Kaiwakai}

Kaiwakai merupakan kegiatan di luar perkuliahan yang tidak memiliki satuan kredit semester $(S K S)$. Kegiatan ini telah ada sejak Program Studi D-III Bahasa Jepang SV UGM berdiri di tahun 1999 di Fakultas Ilmu Budaya UGM,dan pada akhirnya bergabung dengan Sekolah Vokasi UGM di tahun 2009. Dalam kegiatan ini, mahasiswa berkesempatan berinteraksi dengan penutur asli BJ dalam situasi informal.

Penanggung jawab Kaiwakai adalah dosen tetap di Program Studi D-III Bahasa Jepang. Pada pelaksanaannya kegiatan ini dijalankan oleh koordinator yang merupakan mahasiswa yang ditunjuk oleh penanggung jawab kegiatan. Koordinator bertugas menghubungi penutur asli yang direkomendasikan oleh penanggung jawab. Koordinasi meliputi jadwal kegiatan yang menyesuaikan dengan perkuliahan peserta, dan juga penutur asli yang biasanya merupakan mahasiswa Jepang yang sedang belajar di kota Yogyakarta. Pada pelaksanaannya, pihak program studi yang menentukan jadwalnya, dan kemudian mencari penutur asli yang dapat hadir di jadwal tersebut. 
Selain berkoordinasi dengan penutur asli, tugas koordinator adalah merancang tema yang akan dibicarakan dalam Kaiwakai. Koordinator dapat berkonsultasi dengan penutur asli untuk memutuskan topik yang akan dibicarakan pada hari tersebut. Tema-tema yang dibicarakan beragam, dapat berupa obrolan bebas dengan topik tertentu, atau me-review pelajaran BJ yang telah diterima di kelas.

Berdasarkan wawancara penulis dengan salah seorang penutur asli yang pernah ikut kegiatan Kaiwakai ${ }^{1}$, praktik Kaiwakai sebelum tahun 2016 banyak didominasi oleh penutur asli sebagai pihak yang menentukan topik kegiatan pada hari tersebut. Kegiatan Kaiwakai yang diobservasi penulis adalah Kaiwakai pada tahun 2016-2017 yang diikuti oleh angkatan 2015 dan 2017. Pada Kaiwakai di tahun ini, koordinator yang menentukan topik yang akan dibicarakan di kelas. Berikut ini adalah tabel yang menunjukkan perbedaan kegiatan Kaiwakai sebelum tahun 2016 dan kegiatan Kaiwakai tahun 20162017 yang diobservasi oleh penulis.

Tabel 1. Persamaan dan Perbedaan Kaiwakai s/d 2015 dan Kaiwakai 20162017

\begin{tabular}{|l|l|l|}
\hline & \multicolumn{1}{|c|}{$\begin{array}{c}\text { Kaiwakai s/d tahun } \\
2015\end{array}$} & \multicolumn{1}{c|}{ Kaiwakai 2016-2017 } \\
\hline $\begin{array}{l}\text { Penanggung } \\
\text { jawab }\end{array}$ & Dosen & Dosen \\
\hline Koordinator & Penutur Asli & Mahasiswa yang ditunjuk dosen \\
\hline Ide kegiatan & Penutur Asli & Koordinator (mahasiswa yang ditunjuk) \\
\hline Animo peserta & Selalu penuh & $\begin{array}{l}\text { Naik turun (terkadang ramai, dan } \\
\text { terkadang sepi) }\end{array}$ \\
\hline
\end{tabular}

(Sumber: Dokumentasi penulis tentang Kaiwakai 2018)

\section{b. Persepsi Mahasiswa Terhadap Kegiatan Kaiwakai}

Persepsi adalah penerimaan sadar, seleksi, pemrosesan dan interpretasi informasi oleh otak kita melalui semua indra. Persepsi juga digunakan untuk menggambarkan apa yang dirasakan (Werner-Franz.H \& Ruggiera,S, 2009). Persepsi juga merupakan pengalaman tentang objek peristiwa, atau hubungan-hubungan yang diperoleh dengan menyimpulkan informasi dan menafsirkan pesan. Persepsi berarti memberikan makna pada stimulus inderawi (Sensory Stimulus). Dalam Pengertian persepsi terdapat muatan muatan, yaitu: (1) adanya proses penerimaan stimulus melalui alat indera, (2) adanya proses psikologis di dalam otak, (3) adanya kesadaran dari apa yang telah diinderakan, (4) memberikan makna pada stimulus. (Jalaluddin Rahmat, 2004). Pada dasarnya persepsi terbentuk melalui 3 proses, yaitu proses seleksi (selection), organisasi (organization), dan interpretasi (interpretation) (University of Minnesota, 2016). Berikut ini adalah penjabaran proses terbentuknya persepsi peserta Kaiwakai yang diadakan di Program Studi D-III Bahasa Jepang SV UGM. Pembentukan persepsi akan disarikan melalui hasil wawancara terhadap 6 responden yang merupakan peserta Kaiwakai tahun 2016-2017. 3

\footnotetext{
${ }^{1}$ Data penelitian 2018
} 
di antaranya adalah mahasiswa angkatan 2015 dan sisanya adalah mahasiswa angkatan 2017.

\section{1) Selection}

Mahasiswa yang menjadi objek penelitian telah mendapatkan sosialisasi tentang kegiatan Kaiwakai baik oleh dosen pengampu mata kuliah Berbicara atau informasi dari mahasiswa angkatan sebelumnya. Pada saat sosialisasi ini telah dijelaskan pentingnya praktik berbicara dengan penutur asli dari bahasa yang sedang dipelajari. Setiap dosen BJ di SV UGM juga selalu menjelaskan bahwa ilmu bahasa tidak hanya bisa dipelajari di perkuliahan, ilmu bahasa harus dipraktikkan dalam keseharian untuk dapat menguasai keterampilan berbahasa asing.

Mahasiswa yang telah mendapatkan sosialisasi kemudian merespon stimulus ini dengan tindakan. Dalam proses terbentuknya persepsi, stimulus (rangsangan) akan diproses melalui indra dan kemudian berbagai faktor akan mempengaruhi individu tersebut dalam menentukan tindakan (Fiske \& Taylor dalam University of Minnesota, 2016). Sebagai sebuah proses, pembentukan persepsi harus melalui kelima indra terlebih dahulu sebelum pada akhirnya si individu menentukan apa yang akan dilakukannya terhadap stimulus yang masuk. Para mahasiswa yang mendaparkan stimulasi berupa anjuran untuk mengikuti Kaiwakai kemudian memilih untuk mencoba mengikuti kegiatan tersebut. Pilihan ini telah dipengaruhi oleh berbagai faktor, antara lain faktor expectation (harapan), dan salient information (stimulus yang menonjol). Dalam stimulus berupa anjuran dari dosen, terdapat expectation (harapan) peserta untuk bisa mahir berbicara BJ dengan penutur asli dan juga salient information (stimulus yang menonjol), yaitu interaksi langsung dengan penutur asli BJ. Berikut adalah hasil wawancara dengan 6 responden yang menunjukkan faktor-faktor yang membuat mereka mengikuti kegiatan Kaiwakai.

Tabel 2. Daftar Jawaban Responden Tentang Alasan Mengikuti Kaiwakai

\begin{tabular}{|c|l|l|}
\hline No & \multicolumn{1}{|c|}{$\begin{array}{c}\text { Nama/ } \\
\text { angkatan }\end{array}$} & \multicolumn{1}{c|}{ Jawaban } \\
\hline 1 & A / 2015 & $\begin{array}{l}\text { alasannya.kalau saya sih dulu.kalau awalnya yang bikin } \\
\text { menarik adalah kan Kaiwakai itu dulu diisi oleh Native } \\
\text { langsung. Jadi kan kalau di kelas itu mata kuliah yang diajar } \\
\text { native itu Cuma 1 semester.... } \\
\text { Awalnya saya tertarik awalnya siapa tahu saya bisa ngobrol } \\
\text { banyak... Ya udah dari situ. Jadi kaya ya kebetulan kaya } \\
\text { kapan lagi gitu ini kan kesempatan yang ga bisa dicari di } \\
\text { mana-mana. Apalagi masih semester 2 ngomongnya masih } \\
\text { ecek-ecek gitu. Kan masih butuh bantuan dari Sensei. Jadi } \\
\text { waktu tu bener-bener ikut terus lah maksudnya biar jadi } \\
\text { semangat dulu lah. }\end{array}$ \\
\hline 2 & $\begin{array}{l}\text { Kita bisa dengan bebas bicara dengan orang Jepang } \\
\text { langsung dan itu dapat membantu kita untuk terbiasa } \\
\text { mengucapkan atau bicara dengan orang Jepang } \\
\text { langsung,jadi bisa menambah wawasan, menambah apa ya }\end{array}$ \\
\hline
\end{tabular}




\begin{tabular}{|c|l|l|}
\hline & & $\begin{array}{l}\text { namnya menambah pengetahuan, skill juga dalam berbicara. } \\
\text { Jadi kita terbiasa dan tidak usah malu-malu lagi. }\end{array}$ \\
\hline 3 & $\mathrm{R} / 2015$ & $\begin{array}{l}\text { Menurut saya, Kegiatan ini untuk mendekatkan siswa } \\
\text { bahasa Jepang pada orang Jepang untuk meningkatkan } \\
\text { kemampuan bahasa jepang teutama hatsuon dan percakapan } \\
\text { dalam bahasa Jepang (Kaiwa) }\end{array}$ \\
$\ldots$ & $\begin{array}{l}\text { Memperluas jaringan orang Jepangnya aja sih. Yaa, buat } \\
\text { buat main. Buat maksudnya, bisa sekalian kaiwa di luar } \\
\text { kelas. Kalau misalnya sekalian main sekalian kaiwa. }\end{array}$ \\
\hline 4 & $\mathrm{H} / 2017$ & $\begin{array}{l}\text { Senang ikut kegiatan Kaiwakai, karena bisa bertemu } \\
\text { berinteraksi dengan orang Jepang dan membuat hubungan } \\
\text { pertemanan ... Manfaatnya bisa meningkatkan kemampuan } \\
\text { berbicara bahasa Jepang, menambah kosakata baru dan } \\
\text { pengetahuan-pengetahuan baru. }\end{array}$ \\
\hline 5 & $\mathrm{~N} / 2017$ & $\begin{array}{l}\text { Sebelumnya tidak tahu apa itu Kaiwakai, apa seperti apa. } \\
\text { Setelah ikut, ternyata oh ternyata saya bisa berdiskusi } \\
\text { langsung dengan orang Jepang saya juga tahu tentang logat- } \\
\text { logat Jepang di sana. }\end{array}$ \\
\hline 6 & AL / 2017 & $\begin{array}{l}\text { Kaya Fukuoka, contohnya “ kamu mau ambil itu?" bahasa } \\
\text { Jepangnya "Otototo" } \\
\text { Seneng, soalnya bener-bener ketemu trus bisa bener-bener } \\
\text { kenalan dengan orang Jepang. .... } \\
\text { Sangat bermanfaat bisa tahu kosakata baru, bisa } \\
\text { membangun relasi dengan orang Jepang, bisa tahu } \\
\text { kebudayaan-kebudayaan Jepang. Belajar bahasanya sih } \\
\text { yang paling penting. }\end{array}$ \\
\hline
\end{tabular}

(Sumber: Dokumentasi penulis tentang Kaiwakai 2018)

Faktor dari lingkungan sekitar akan memperngaruhi pembentukan persepsi. Stimulus berupa anjuran dari dosen untuk ikut mengikuti Kaiwakai dengan beberapa alasannya telah membuat responden mencoba mengikuti kegiatan ini. Misalnya $\mathrm{R}$, ia selain ingin lebih mahir berbicara dengan BJ, juga ingin menjalin kedekatan dengan penutur asli di luar kampus dengan tetap memiliki harapan ingin sekaligus melatih kemampuan BJ nya. Responden $\mathrm{N}$ tidak tahu tentang kegiatan Kaiwakai, namun ia mengikuti Kaiwakai pertama kali hanya karena disuruh oleh dosen. Pada akhirnya $\mathrm{N}$ memutuskan untuk rutin hadir di Kaiwakai karena mendapakan stimulus baru, yaitu pengetahuan budaya dari hasil interaksinya dengan penutur asli. Pengaruh dari pengalaman, seperti A yang membandingkan pengalaman bahwa kuliah bersama penutur asli di SV UGM sangat terbatas, membuatnya tertarik untuk ikut Kaiwakai.

Dari tabel 2 dapat diketahui bahwa responden baik dari angkatan 2015 maupun 2017 mengikuti kegiatan Kaiwakai karena alasan kehadiran penutur asli di dalamnya. Mereka mengikuti Kaiwakai dengan harapan melalui interaksi langsung dengan orang Jepang, 
akan dapat menambah wawasan dan pengetahuan tentang negara Jepang dan meningkatkan kemampuan BJ terutama dari segi kemampuan berbicara.

\section{2) Organization}

Pengorganisasian adalah bagian kedua dari proses persepsi, di mana kita memilah dan mengelompokkan informasi yang kita rasakan berdasarkan pola kognitif bawaan dan yang dipelajari. Cara memilah-milah informasi ialah dengan mengkategorikannya berdasarkan kedekatan, kesamaan, dan perbedaan informasi yang diindera oleh kelima indra (Coren, 1980 dalam University of Minnesota, 2016). Tahap pengorganisasian dalam pembentukan persepsi terhadap kegiatan Kaiwakai dianalisis dari hasil wawancara yang mempertanyakan kendala yang muncul pada saat Kaiwakai. Berikut ini adalah rangkuman kendala yang ditemui ketika ikut kegiatan Kaiwakai beserta cara responden mengatasi kendala tersebut.

Tabel 3. Daftar Jawaban Responden Tentang Kendala di Kaiwakai dan Cara Mengatasinya

\begin{tabular}{|c|l|l|}
\hline No & \multicolumn{1}{|c|}{$\begin{array}{c}\text { Nama/ } \\
\text { angkatan }\end{array}$} & \multicolumn{1}{c|}{ Jawaban } \\
\hline 1 & A / 2015 & $\begin{array}{l}\text { Kaiwakai 1-nensei prakteknya tidak harus pakai kertas, ga } \\
\text { harus ngisi-ngisi. Tapi kita diajak bermain kaya pakai kartu. } \\
\text { Apa tu kaya karuta gitu....Jadi nggak ada media yang terlalu } \\
\text { menyulitkan seperti menulis. } \\
\text { Di 2-nensei seperti topik yang sederhana, jadi terarah hari ini } \\
\text { ngomongin apa, besok apa. Biasanya dari situ juga belajar hal- } \\
\text { hal baru, jadi kaya perbandingan bahasa. Misalnya jatuh,. } \\
\text { Jatuh cinta dalam bahasa Jepang ada istilah sendiri. } \\
\text { Cara Mengatasi: } \\
\text { Tetap mengikuti Kaiwakai, mengambil sisi positif dari } \\
\text { Kaiwakai (manfaat yang diperoleh, misalnya kosakata baru) } \\
\text { (tidak ada narasi spesifik) }\end{array}$ \\
\hline 2 & $\begin{array}{l}\text { Ichinensei, Kesannya ... Kenalnya itu cuman dari } \\
\text { pengampunya, (dia) ngarahin kaya gini, kaya gini trus } \\
\text { langsung ditunjuk gitu, satu satu. Pas 2-nensei, kelompoknya } \\
\text { sendiri-sendiri. Pas datang tu dah pada ngumpul. Jadi bingung } \\
\text { harus bagaimana. } \\
\text { Misalnya waktu itu ada kelompoknya Hasan, mereka udah } \\
\text { saling kenal, jadi susah masuknya. Kalau misalnya saya, yang } \\
\text { tidak kenal dengan mereka mau masuk itu jadi susah. } \\
\text { Cara Mengatasi: }\end{array}$ \\
\hline
\end{tabular}




\begin{tabular}{|c|c|c|}
\hline & & $\begin{array}{l}\text { Bertanya pada orang lain } \\
\text { Narasi: } \\
\text { Kalau pas 1-nensei, dari saya kalau misalnya dari segi } \\
\text { keterbatasan kotoba itu, saya biasanya nanya dulu sama } \\
\text { teman. ini bener ga. kan karena masih nunggu giliran. } \\
\text { Kalau pas 2-nensei karena kita interaksi langsung. A. Saya } \\
\text { biasanya secara pelan-pelan ngomongnya. Kaya gini bener ga, } \\
\text { jadi langsung kakunin sama nihonjin-nya. } \\
\text { Jadi waktu itu pernah saya ngomong sama teman kaya gini, } \\
\text { tapi teman saya bilang jangan kaya gini. } \\
\text { ngomong dengan teman, minta koreksi teman dan bisa } \\
\text { langsung dengan nihonjin. }\end{array}$ \\
\hline 3 & $\mathrm{R} / 2015$ & $\begin{array}{l}\text { 1-nensei sih deg degan karena kan sama orang Jepang, terus } \\
\text { merasa kemampuan bahasa Jepangnya kan kurang, kalau } \\
\text { ngomong takut. } \\
\text { Kalau 2-nensei dah lebih enjoy. Kalau tidak tahu bisa nanya } \\
\text { ke Nihonjin. Deg-deg an juga sih hahaha.. } \\
\text { Cara Mengatasi: } \\
\text { Bertanya pada orang lain, baik pada teman maupun penutur } \\
\text { asingnya secara langsung. } \\
\text { Narasi: } \\
\text { Kalau bingung saya nanya aja ke S sensei gitu. } \\
\text { 2-nensei dah lebih enjoy, ya sih kalau tidak tahu bisa nanya } \\
\text { ke Nihoniin. Deg-deg an juga sih hahaha.. }\end{array}$ \\
\hline 4 & H / 2017 & $\begin{array}{l}\text { Sebagai koordinator, kendalanya adalah pada saat } \\
\text { koordinasi, karena harus menggunakan bahasa Jepang. Arah } \\
\text { kegiatannya bagaimana, menjelaskan gitu. } \\
\text { Ada kendala ketika berkelompok, misalnya Temen-temen } \\
\text { termasuk nihonjin sulit untuk rolling,karena sudah nyaman } \\
\text { mengobrol. Biasanya melewati batas waktu yang ditentukan. } \\
\text { Deg degan,karena pertama kali berbicara dengan bahasa } \\
\text { Jepang langsung dengan orang Jepang. } \\
\text { Cara mengatasi : }\end{array}$ \\
\hline
\end{tabular}




\begin{tabular}{|c|c|c|}
\hline & & $\begin{array}{l}\text { Tidak kapok berinteraksi dengan orang Jepang. Jika tidak } \\
\text { bisa bahasa Indonesia, maka saya memakai bahasa Jepang } \\
\text { sederhana dengan pelan-pelan/lambat. }\end{array}$ \\
\hline 5 & $\mathrm{~N} / 2017$ & $\begin{array}{l}\text { Merasa kesulitan. Ada yang masih malu, ini orang Jepangnya } \\
\text { gimana ni, bersahabat enggak. Orang Jepang ada yang } \\
\text { pendiam juga... } \\
\text {...mmm. kalau saya susah bahasanya, dia ngerti enggak kalau } \\
\text { saya ngomong gini. } \\
\text { Cara Mengatasi: } \\
\text { Diatasi dengan lihat google translate atau kadang bawa kamus } \\
\text { juga. }\end{array}$ \\
\hline 6 & AL / 2017 & $\begin{array}{l}\text { Iya kesusahan. Suka minder dengan teman-teman yang dulu } \\
\text { waktu SMA pernah belajarbahasa Jepang. Jadinya susah, tapi } \\
\text { berkat Kaiwakai itu juga saya bisa tahu kosakata lebih banyak. } \\
\text { Soalnya tanya temen. } \\
\text { Cara Mengatasi: } \\
\text { tapi berkat Kaiwakai itu juga saya bisa tahu kosakata lebih } \\
\text { banyak. Soalnya tanya temen. }\end{array}$ \\
\hline
\end{tabular}

(Sumber: Dokumentasi penulis tentang Kaiwakai 2018)

Responden A, LA, dan R yang merupakan angkatan 2015 telah mengikuti kegiatan Kaiwakai yang diampu oleh dosen lain sebelum penelitian ini diadakan. Jawaban mereka menunjukkan perbandingan antara Kaiwakai sebelum tahun 2016, sewaktu mereka masih di tingkat pertama (ichinensei) dan setelahnya. Hal ini menunjukkan proses organisasi yang mencari kesamaan dan perbedaan informasi kondisi aktual Kaiwakai dengan pengalaman mereka di Kaiwakai di tahun sebelumnya. Dapat dilihat bahwa A tidak menjelaskan secara spesifik kendala yang ditemuinya saat Kaiwakai, namun tampak bahwa ia tidak terlalu menyukai Kaiwakai yang menggunakan lembar kerja yang harus diisi dalam kegiatannya. LA dalam jawabannya menunjukkan kesulitan berbaur dengan penutur asli dalam kelompok-kelompok kecil, tidak seperti saat 1-nensei. Sedangkan $\mathrm{R}$ menunjukkan kesulitan yang ditengarai oleh keterbatasan kemampuan bahasa ketika masih di semester 1 .

Selanjutnya pada tabel di atas, responden H, N, dan AL dari angkatan 2017 mengutarakan kendala bahasa, karena mereka masih duduk di tingkat pertama dan baru pertama kali berinteraksi dengan penutur asli. H sebagai koordinator Kaiwakai 2017 merasa kesulitan berkomunikasi dengan penutur asli dalam BJ, karena sebelumnya belum pernah berinteraksi dengan orang Jepang. AL yang tidak memiliki pengalaman belajar BJ di SMA merasa tidak percaya diri. Ia tampaknya membandingkan kemampuannya dengan teman-teman lain yang lebih mahir. Organisasi informasi yang dilakukan responden dari angkatan 2017 menunjukkan bahwa mereka mengatur stimulus ini berdasarkan perbedaan sebelum dan sesudah berinteraksi dengan penutur asli. Pada ketiganya muncul rasa malu 
ketika harus berbicara dengan orang asing dan juga rasa tidak percaya diri pada kemampuan BJ nya.

Tahap pengorganisasian mengacu pada bagaimana stimulus yang telah diterima dan diseleksi tersebut bertahan atau meningkat menjadi konflik yang akan menentukan persepsi seperti apa yang akan muncul terhadap kegiatan Kaiwakai. Dari proses kedua pembentukan persepsi ini, para responden menemukan kendala dalam kegiatan Kaiwakai. Cara responden mengatasi kendala ini akan menjadi skemata yang penting bagi tahap berikutnya. Tahap terakhir, yaitu interpretation akan menjelaskan skemata yang membentuk persepsi yang muncul terhadap kegiatan Kaiwakai.

\section{3) Interpretation}

Setelah mengikuti kegiatan Kaiwakai, peserta dapat mengingat pengalaman apa saja yang pernah diperoleh dari kegiatan ini. Peserta kemudian menyampaikan interpretasinya tentang kegiatan Kaiwakai sebagai tahap akhir dari pembentukan persepsi.Meskipun menyeleksi dan mengorganisir informasi mudah dilakukan, bahkan terkadang dilakukan dengan tanpa sadar, interpretasi akan terasa lebih rumit. Menginterpretasikan sesuatu, berarti memaknai pengalaman yang kita miliki menggunakan struktur mental yang dikenal dengan schemata (skemata)

Yang dimaksud dengan skemata adalah sebuah struktur kognitif intelektual individu berupa representasi, persepsi, ide, dan aksi yang diasosiasikan. Hasil asosiasi ini merupakan dasar pemikiran yang digunakan untuk beradaptasi dengan lingkungan dan mengaturnya untuk memahami pengetahuan baru (Piaget dalam Rudell, 2005). Lebih lanjut, setiap pengalaman yang dialami termasuk di dalamnya bahasa, istilah dan atribut dicamkan oleh individu, membentuk jaringan pemetaan tunggal yang disebut dengan skemata. Banyaknya pengalaman individu menggabungkan skemata-skemata menjadi skema yang membentuk pola pikir terhadap suatu hal (Satiadharma, M.P, 2001). Skemata membantu dalam memaknai suatu hal berdasarkan pengetahuan dan pengalaman masa lalu.

Dari 2 proses sebelumnya, yaitu seleksi dan organisasi, dapat dipahami bahwa 6 peserta Kaiwakai ini merespon stimulus dan mengorganisasinya dengan berbagai faktor yang ada di sekitar mereka. Mereka pada akhirnya memilih mengikuti Kaiwakai karena terdapat kesesuaian dengan apa yang menjadi tujuan mereka (proses organisasi). Selama mengikuti kegiatan Kaiwakai selama 2 semester, responden menemui kendala yang mempengaruhi pembentukan persepsi mereka tentang Kaiwakai. Dalam teori pembentukan persepsi, individu yang berhasil mengatasi kendala dapat dikatakan berhasil beradaptasi di dalam sebuah situasi. (University of Minnesota, 2016). Proses adaptasi memerlukan kesungguhan, sebab individu senantiasa menggunakan skema lama. Dalam hal ini para peserta Kaiwakai yang menemui kendala bisa gagal beradaptasi jika tetap berpegang pada skema lama, yaitu bahwa komunikasi dengan penutur asli adalah hal yang sulit dan menimbulkan rasa tidak percaya diri. Satiadharma (2001) menjelaskan bahwa pengalaman individu membentuk skema yang membentuk pola pikir terhadap sesuatu, dalam hal ini yang dituju adalah persepsi terhadap kegiatan Kaiwakai.

Skemata responden yang menunjukkan bahwa mereka telah beradaptasi ditunjukkan dengan cara-cara mengatasi kendala bahasa, misalnya responden R, dan AL yang pada awalnya malu-malu berbicara dengan orang Jepang, menjadi lebih percaya diri. A dan $\mathrm{H}$ menunjukkan adaptasinya dengan tetap rajin mengikuti Kaiwakai. Adaptasi terhadap kendala yang muncul membuat peserta Kaiwakai menilai Kaiwakai sebagai suatu 
kegiatan yang positif. Adaptasi juga berhasil dilakukan berkat skema awal bahwa Kaiwakai akan meningkatkan kemampuan BJ. Setelah melewati kendala, responden menunjukkan interpretasi positif. Interpretasi positif ini berwujud paparan mengenai pentingnya kegiatan Kaiwakai yang dirangkum dari hasil wawancara yang mempertanyakan perlu atau tidaknya kegiatan Kaiwakai di kemudian hari dalam tabel 4, sebagai berikut:

Tabel 4. Daftar Jawaban Responden Tentang Pentingnya Kegiatan Kaiwakai

\begin{tabular}{|c|c|c|}
\hline No & $\begin{array}{c}\text { Nama/ } \\
\text { angkatan }\end{array}$ & Jawaban \\
\hline 1 & $\mathrm{~A} / 2015$ & $\begin{array}{l}\text { Mendengar cerita dari kohai, bisa dibilang kehadiran yang } \\
\text { sedikit, memang awalnya kalau yang saya lihat,mereka } \\
\text { tutidak berminat pada bahasa Jepang, dan justru karena } \\
\text { kasusnya kaya saya,saya pikir mereka harus mencoba ikut. } \\
\text { Ga selamanya kita bisa cari native sendiri. Sudah ada } \\
\text { fasilitas sebaiknya dimanfaatkan. }\end{array}$ \\
\hline 2 & LA/ 2015 & $\begin{array}{l}\text { Kalau dari saya yang sudah ngerasainmanfaatnya itu lebih } \\
\text { baik diterusin, soalnya kan kita jarang banget ni kedatangan } \\
\text { orang jepang untuk mengobrol. Kalau di kelas kan orang } \\
\text { Jepangnya Cuma disuruh Sensei ngapa gitu, kalau di } \\
\text { Kaiwakai jadi bebas. }\end{array}$ \\
\hline 3 & $\mathrm{R} / 2015$ & $\begin{array}{l}\text { Perlu Sensei. Memperluas jaringan orang jepangnya aja sih. } \\
\text { Yaa buat buat main. Buat maksudnya, bisa sekalian kaiwa di } \\
\text { luar kelas. Kalau misalnya sekalian main sekalian kaiwa . } \\
\text { biasanya anak-anak suka jalan-jalan, sekalian guiding. }\end{array}$ \\
\hline 4 & H / 2017 & $\begin{array}{l}\text { Perlu, karena untuk semester selanjutnya materi semakin } \\
\text { bertambah,kosakata juga semakin bertambah ... } \\
\text { Teman-teman juga butuh seperti belajar kelompok terutama } \\
\text { dengan orang Jepang. Karena sumber aslinya emang dari } \\
\text { orang Jepang. Dan a Orang Jepang ketika aa mengajarkan } \\
\text { sesuatu itu lebih mudah dimengerti karena sumber } \\
\text { informasinya langsung. }\end{array}$ \\
\hline 5 & $\mathrm{~N} / 2017$ & $\begin{array}{l}\text { Sangat perlu sekali. Biar semakin lancar dan tidak mudah } \\
\text { lupa kosakata, bunpo, dan keberanian untuk menyapa orang } \\
\text { Jepang } \\
\text { Saya punya teman orang Jepang jadi saya punya banyak } \\
\text { relasi untuk misalnya saya kerja atau bertamasya ke Jepang, } \\
\text { nginepnya bisa ke teman orang Jepang, atau ada pemandu } \\
\text { ketika di sana. } \\
\text { Kekurangan Kaiwakai yaa jamnya terlalu sore. } \\
\text { Pengennya Cuma orang Jepangnya semakin banyak saja. }\end{array}$ \\
\hline
\end{tabular}




\begin{tabular}{|c|l|l|}
\hline 6 & AL/2017 & $\begin{array}{l}\text { Kaiwakai sangat diperlukan. Terutama untuk anak 1-nen. } \\
\text { Kalau menurut saya, 1-nen itu kan masih masa peralihan dari } \\
\text { masa SMA ke kuliah itu beda banget, Sensei. Trus kasihan } \\
\text { juga sama yang dari SMA belum pernah dapat Bahasa } \\
\text { Jepang. Jadi di Kaiwakai ini sangat membantu. Jadi tahu } \\
\text { kosakata, bunpo, dan pokoknya berani ngomong. Soalnya } \\
\text { bisa nanya ke temen-temen juga. }\end{array}$ \\
$\begin{array}{l}\text {..Sudah bagus. Efektif dengan grup, tetapi topiknya } \\
\text { ditentukan dengan jelas supaya tidak random ke mana-mana }\end{array}$ \\
\hline
\end{tabular}

(Sumber : Dokumentasi penulis tentang Kaiwakai 2018)

Dari jawabannya, A menunjukkan persepsi positif pada kegiatan Kaiwakai. Ia berharap adik kelasnya nanti akan mengikuti jejaknya untuk rajin ikut Kaiwakai. A mengaku bahwa ia tertarik pada BJ baru setelah mengikuti kegiatan Kaiwakai,karena di sini ia bisa berinteraksi langsung dengan penutur asli. 5 responden lainnya menunjukkan persepsi positif dengan memaparkan manfaat mengikuti kegiatan ini, antara lain untuk meningkatkan kemampuan BJ, terutama kemampuan berbicara dalam BJ. Selain peningkatan kemampuan $\mathrm{BJ}$, responden juga mendapatkan pengalaman berinteraksi dengan budaya negara lain.

\section{Penutup}

Kegiatan Kaiwakai merupakan kegiatan di luar perkuliahan yang memfasilitasi mahasiswa Program Studi D-III Bahasa Jepang di SV UGM untuk berinteraksi dengan penutur asli. 6 peserta Kaiwakai tahun 2016-2017 yang terdiri dari 3 mahasiswa angkatan 2015 dan 3 mahasiswa angkatan 2017 berdasarkan analisis proses pembentukan persepsi, menunjukkan persepsi positif pada kegiatan ini.

Persepsi adalah penerimaan sadar, seleksi, pemrosesan dan interpretasi informasi oleh otak kita melalui semua indra. Persepsi juga digunakan untuk menggambarkan apa yang dirasakan (Werner-Franz.H \& Ruggiera,S, 2009). Persepsi tersebut ditunjukkan dengan interpretasi mereka terhadap kegiatan Kaiwakai beserta kendala yang pernah ditemui selama kegiatan. Interpretasi keenam responden menggambarkan bahwa kegiatan Kaiwakai adalah kegiatan positif yang layak untuk terus diadakan di kemudian hari.

Dalam proses memperoleh persepsi positif ini, responden harus mengatasi kendala yang muncul ketika mengikuti kegiatan Kaiwakai. Keberhasilan mengatasi kendala yang muncul menunjukkan cognitive complexity (kompleksitas kognitif), yang penting bagi kompetensi komunikasi seorang individu. Persepsi positif para peserta ini tidak lain juga menunjukkan bahwa dengan proses mengadaptasikan skema lama (pengalaman pada saat menghadapi kendala) menuju skema baru (kondisi setelah berhasil mengatasi kendala), hal itu merupakan bagian dari pembelajaran yang harus dilalui seseorang untuk dapat memberikan makna bagi tindakan yang dipilihnya. Responden dalam penelitian ini mendapatkan efek positif Kaiwakai setelah mereka bertahan dengan pilihannya untuk mengikuti kegiatan ini berproses dalam mengatasi rasa malunya dalam berinteraksi dengan penutur asli BJ.

\section{Daftar Pustaka}


Andreou, G. \& Galantomos I, 2009. The Native Speaker Ideal in Foreign Language Teaching. Electronic Journal of Foreign Language Teaching 2009, Vol. 6, No. 2, hal. 200-208.

Bungin, B. 2007. Penelitian Kualitatif: Komunikasi, Ekonomi, Kebijakan Publik, dan Ilmu Sosial Lainnya. Jakarta: Kencana Prenada Media Group.

Jalaludin, R. 2004. Psikologi Komunikasi. Bandung: PT Remaja Rosdakarya

Rudell, R.M. 2005.Teaching Content Reading and Writing. Fouth Edition. USA: Hermitage Publishing Services.

Satiadharma, M.P, 2001. Persepsi Orang Tua Membentuk Perilaku Anak: Dampak Pygmalion di dalam Keluarga. Jakarta : Yayasan PT Pustaka Obor Indonesa

Sutedi, D. 2017. Dinamika Perkembangan Pendidikan Bahasa Jepang di Indonesia dan Permasalahannya. Prosiding Seminar Nasional Dinamika Perkembangan Bahasa Jepang di Indonesia.Universitas Muhammadiyah Yogyakarta, 9 Desember 2017. Hal 7-13. Cetak.

The Japan Foundation (2017). Survey Report on Japanese Language Education Abroad 2015. Tokyo: Kuroshio Publisher.

University of Minnesota. 2016. Communication In Real World Perception Process. Minnesota: M. Libraries Publishing

http://open.lib.umn.edu/communication/chapter/2-1-perception-process/ DOI https://doi.org/10.24926/8668.0401. diakses 8 Juli 2018.

Werner-Franz.H \& Ruggiera,S.2009. Building Leadership in Project amd Network Management: a Facilitartor Tool Set. New York : Springer Publishing. DOI 10.1007/978-3-540-93956 